Review Article

\title{
Industrial Microbiology: Current Status of Research \& Development in India
}

\author{
BHUPINDER SINGH CHADHA* \\ Department of Microbiology, Guru Nanak Dev University, Amritsar 143 005, India
}

(Received on 03 April 2019; Accepted on 05 November 2019)

\begin{abstract}
Bio-Industrial Sector in India is still in its infancy, but growing steadily at CAGR of $11.2 \%$ accounting for total sales of USD 128 Millions. The multinational companies account for nearly $65 \%$ of the market, while the rest is met by the local industries. The Indian bio-industries are now reassessing and increasing their R\&D capabilities and technical staff, establishing production units and developing an elaborate distribution system. The major industries employing microbial fermentation in India include alcoholic beverages and industrial ethanol, organic acids, enzymes and recombinant therapeutics. The upcoming lignocellulosics based biorefineries offers an exciting area of R\&D and scale up at industrial level. However, there is urgent need to establish industries for fermentation of novel bio-molecules e. g. amino acids, novel antibiotics, etc. to be self reliant in face of vibrant geopolitical situation.
\end{abstract}

Keywords: Research \& Development; Alcohols; Enzymes; Biochemicals

\section{Introduction}

Industrial microbiology forms the core of white biotechnology and thrives on the ability of selected microorganisms or genes derived thereof for producing important biomolecules/products/proteins. Man has been using the microorganisms since time immemorial. With the advances in the knowledge of genetics, metabolism and physiology, the spectrum of products derived from microorganisms have gone up steadily from the traditional procedures of making wine, leavening of dough for bread making and fermented milk to now advanced therapeutic biomolecules, amino acids, enzymes, solvents and chemicals. The global sale of fermentation-derived products was about $\$ 24.3$ billion in 2015 , which is expected to rise by $44 \%$ in the next five years to $\$ 35.1$ billion that accounts for a compound annual growth rate (CAGR) of 7.7\% (BCC research report FOD020C World Markets for Fermentation Ingredients).

Biochemicals synthesized through fermentation route are used in a variety of applications and serve as important feedstocks for developing commercially viable technologies. The use of these biochemicals

\footnotetext{
*Author for Correspondence: E-mail: chadhabs@yahoo.com
}

by industries world overis primarily due to their being natural moieties that are available at affordable cost due touse of improved strains and process parameters. The major products produced through fermentation include enzymes, organic acids and alcohols that find use in a wide array of industrial processes like drugs and pharmaceuticals, foods and beverages, chemical, textile and rubber industries as prominent end users. The revenue generated through the use of these fermentation products was USD 41.568 billion in 2012, which is slated to reach USD 60.124 billion by 2019 at an annual growth of $5.4 \%$.

Alcohols (potable liquor, solvents and blenders in fuels) were identified as the major contributor to the global fermentation based chemical market in 2012, with enzymes and organic acids being other important commodities. The revenues generated from sale of alcohol alone was USD 22.377 billion in 2012 which was more than half (53.8\%) of the total consumption of fermentation derived molecules. The other major segments of fermentation products include aminoacids, enzymes, organic acids and antibiotics in that order, even vitamins and xanthan gum have contributed significantly to the sales (Fig. 1). 
SUMMARY FIGURE

GLOBAL MARKET FOR FERMENTATION PRODUCTS, 2008 AND 2013

(\$ MILLIONS)

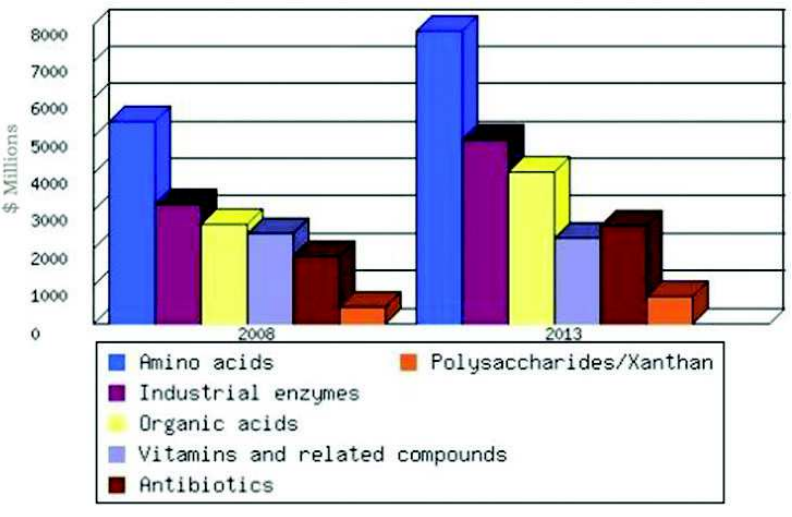

Source: BBC Research

Fig. 1: Market share of major fermentation products in 2008 and 2013 (Source: www.transparencymarketresearch. com)

Geographically North America is the major and the most important market for the biochemical industry which is mainly due to steady rise in the pharmaceutical sector in U.S.A. In recent times Asia Pacific has emerged as the next important market for the fermentation based biochemicals. The North American and European markets are now reaching a plateau and future projections see Asia Pacific as strong bastion for growth. The consistent rise in food and beverage, pharmaceutical, healthcare and cosmetic industriesis expected tobethe major future driversof the demand for fermentation chemicals. The quest for green and ecofriendly technologies will further add tothe use of fermentation chemicals. The availability of raw materials, which contribute to around $55-60 \%$ of the product cost in a process, and the fluctuations in their prices are seen as negative factors in attaining smooth market growth. Some of the major companies involved in the production of fermentation chemicals are Ajinomoto Incorporation, Du Pont, Danisco A/S., Roche, BASF SE, Dow Chemical Company, Novozymes A/S and Cargill Incorporation.

\section{Indian Scenario}

Bio-Industrial Sector in India is still in its infancy, but growing steadily at CAGR of $11.2 \%$ accounting for total sales of USD 128 Millions. The multinational companies account for nearly $65 \%$ of the market, while the rest is met by the local industries (FICCI report, 2015). The Indian bio-industries are now reassessing and increasing their $R \& D$ capabilities and technical staff, establishing production units and developing an elaborate distribution system. The major industries based on fermentation in India are listed in Table 1.

The present review provides an insight into the production and R\&D status of the fermentation related industries in India during the last 10 years.

\section{Organic Acids Production}

\section{Lactic Acid}

The demand for lactic acid in India was estimated at 2500 tonnes in the year 2015, which is partially met through imports. Lactochem India Ltd., Chennai, is main producer of lactic acid in India. The company produces natural $\mathrm{L}(+)$ Lactic Acid using cane molasses as carbon source. In recent times, another company Pratishta Industries, Secunderabad, have also ventured into lactic acid production through molasses fermentation. Efforts to replace molasses with cellulosic sugars derived from agro-residues such as sugarcane bagasse is now being tried at Godavari Biorefineries Ltd., using technology transferred from NCL Pune for the production of lactic acid at their demonstration scale bio-refinery facility in Karnataka. The researchers at NCL Pune (Adsul et al., 2007) documented the production of $\mathrm{L}(+)$ lactic acid from cellulose derived from thermo-chemically treated sugarcane bagasse. The treated bagasse cellulose was subsequently hydrolysed using in-house cellulase produced by Penicillium janthinellum mutant EU1 employing Lactobacillus delbrueckii Uc-3 mutant strain that could metabolize cellobiose/cellotriose on addition to glucose in the hydrolysate to lactic acid. The strain produced high levels of lactic acid (67 g / L) from bagasse derived hydrolysate containing $80 \mathrm{~g} /$ Lof sugars. The process registered high productivity of $0.93 \mathrm{~g} / \mathrm{L} / \mathrm{h}$ and yield $\left(Y_{p / s}\right)$ of $0.83 \mathrm{~g} / \mathrm{g}$. Dumbrepatil et al. (2008) further reported that $L$. delbrueckii mutant Uc-3 strain can be used for producing high levels of lactic acid (166 g/l) from molasses achieving a high productivity $(4.15 \mathrm{~g} / \mathrm{L} / \mathrm{h})$. They claimed it to be one of the highest achieved lactic acid yields and productivity and advocated $L$. delbrueckii mutant Uc-3 as the potential strain for economical production of lactic acid from molasses. 
Table 1: Industrial Microbiology related fermentation industries in India

\begin{tabular}{|c|c|c|}
\hline Industry & Products & Application \\
\hline Advanced Enzyme Technologies, Thane & Enzymes & Human, Healthcare, Textile, Leather, Food \\
\hline Alembic, Vadodara & Pharma products, Erythromycin, Penicillin & R\&D in Chemistry, Pharmaceuticals \\
\hline Alltech Biotechnology, Bangalore & Natural yeast and Enzymes technology & Animal feed \\
\hline Americos industry, Ahmedabad & Textile auxiliaries, Smart colorants & Textile \\
\hline Anil Biochem, Ahmedabad & $\begin{array}{l}\text { Enzymes, Microbes, Probiotics, } \\
\text { Gluconates }\end{array}$ & Starch, Textile \\
\hline Biocon India Limited, Bangalore & $\begin{array}{l}\text { Lovastatin, Insulin, Insulin analogs, } \\
\text { Bio-similar, MABs etc. }\end{array}$ & Biopharmaceuticals \\
\hline Corncord Biotech, Ahmedabad & Enzymes, Statins & Food, Feed, Leather, Textile, Pharmaceuticals \\
\hline Fermentor Biotech, Thane & Biocatalyst, Penicillin $\mathrm{G}$ amidase & Pharmaceuticals \\
\hline Gujarat organics, Mumbai & Biochemicals & Pharma,Cosmetics, Agrochemical, Dyes \\
\hline International Panacea, New Delhi & Biofertilizer, BiopesticidesNutraceuticals, & Recombinantproteins, Agriculture health care \\
\hline Lactochem Ltd., Chennai & Lactic acid & Food, Pharmaceuticals \\
\hline LumisBiotech, Mumbai & Industrial Enzymes & Textile, Feed, Food, Paper, Pharma \\
\hline Lupin Pharmaceuticals, Tarapur & Rifampicin, lovastatin, other Statins & Healthcare \\
\hline Maple Biotech, Pune & Cellulose, $\alpha$-cellulose & Pharmaceuticals, Food \\
\hline Maps (India), Ahmedabad & Industrial Enzymes & Food, Feed, Leather, Textile \\
\hline Novozymes,India & Enzymes and biocatalysts & Food, Feed, Ethanol \\
\hline Praj Industries, Pune & 2G ethanol, Bio-diesel & Fuel \\
\hline $\begin{array}{l}\text { Prathista Industries Limited, } \\
\text { Secunderabad }\end{array}$ & $\begin{array}{l}\text { Multizyme, Lactic acid, gluconate, } \\
\text { propionic acid }\end{array}$ & Feed, Food, Pharmaceuticals \\
\hline Porya Chemicals, Mumbai & Amino acids & Nutraceuticals, Poultry, Veterinary \\
\hline Proalgen Biotech, Chennai & $\beta$-carotene & Food, Healthcare \\
\hline Resil Biotech, Bangalore & Enzymes & Food, Feed \\
\hline RPGLife Sciences, Mumbai & Doxorubicin and Epirubicin, cyclosporin & Cancer and Life-saving drugs \\
\hline Rozzari Biotech India, Mumbai & Enzymes & Bioscouring of wool and silk \\
\hline Solaris Biochemicals, Ahmedabad & Citric acid & Food, Chemical \\
\hline SPIC, Chennai & $\begin{array}{l}\text { Fermentors, Fermentation ingredients } \\
\text { for pharmaceuticals }\end{array}$ & Drug intermediates Nutraceuticals \\
\hline Tex Biosciences, Chennai & Enzymes & Textile, Leather, Poultry \\
\hline Zytex, Mumbai & Enzymes & Bakery, Food processing, \\
\hline
\end{tabular}

Dey et al. (2012) demonstrated a green approach for production of lactic acid using sugar cane juice by Lactobacillus delbrueckii in a process that involved membrane based non-neutralizing fermentation process.

\section{Citric Acid}

Citric acid is used by the food processing, cosmetics and detergent industries that was primarily produced (4,000 tons/annum) by Citurgia Biochemical Ltd, Surat) using molasses as substrate (Solomon, 2011).
Later a commercial plant for citric acid fermentation was commissioned in 2003 by BILT (Solaris Biochemicals, Ahmedabad) using Vogelbusch proprietary citric acid production technology that uses Aspergillus niger spores as inoculum and low energy consuming air-lift fermenters. Citric acid production by $A$. niger LPB 21 strain that could utilize cassava bagasse as the substrate was demonstrated at laboratory and semi-pilot scale levels using solid-state fermentation (Vandenberghe et al., 2004). Thermally treated cassava bagasse was found to be suitable for 
Global fermentation chemicals market, 2012 - 2019 (Kilo Tons) (USD Million)

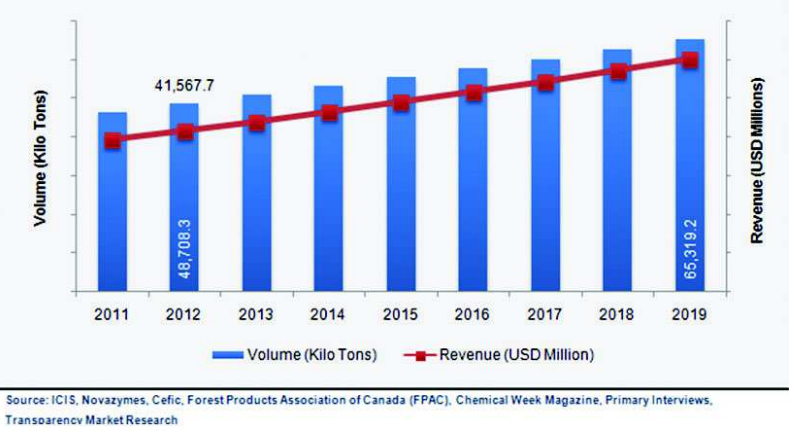

Fig. 2: Expected rise in volume and revenue fermentation products by 2019

achieving enhanced fermentation efficiencyresulting in $220 \mathrm{~g}$ citric acid $/ \mathrm{kg}$ substrate. The process parameters like aeration rate $(60 \mathrm{~mL} / \mathrm{min})$ and initial humidity $(60 \%)$ were critical for achieving production of citric acid ( $265.7 \mathrm{~g} / \mathrm{kg}$ of dry cassava bagasse) in horizontal drum bioreactor. Studies have also been carried out using apple pomace and red sea weed as substrates for the production of citric acid (Kumar et al., 2010; Ramesh and Kalaiselvam, 2011).

\section{Gluconic Acid}

Gluconic acid is mainly produced through electrolysis of glucose. The first gluconic acid fermentation facility was set up by Prathista Industries Limited, Secunderabad in 2004 using aerobic fermentation and suitable down-stream processing based on the technology developed at CSIR (RRL, Jammu). Later, an Indian patent for gluconic acid production by a novel Aspergillus strain describing process for biosynthesis of gluconic acid was obtained (Puri et al., 2007). Mutants of A. oryzae RP-NTG-12, capable of producing $72(\mathrm{~g} / \mathrm{L})$ gluconic acid, have also been reported (Raksha et al., 2012). There is no plant for itaconic acid production in India and hardly any research is being done on this aspect. Similarly, succinic acid fermentation has not yet been replacedby cost-effective chemical method although, succinic acid production by Escherichia coli $(26.2 \mathrm{~g} / \mathrm{L})$ in $30 \mathrm{~h}$ has been reported at fermenter level (Agarwal et al., 2007).

\section{Amino Acids}

Amino acids that are used in food, feed and pharmaceuticals industrieshavea major share of market to the tune of USD 5.4 billion in 2008 and is expected to rise steadily to USD 7.8 billion by 2013 at CAGR of $7.6 \%$. There is no commercial fermentation plant for production of lysine and glutamic acid, therefore, India is totally dependent on imports. Theresearch institutes/industries have not shown interest on amino acid production as they are not very positive about competing with existing amino acid producing power houses (Japan, South Korea and China) for developing commercially viable process (TIFAC report). Some efforts at lab scale levels have been documented, where researchers have designed and evaluated two-stage fermentation strategy and obtained enhanced lysine productivity by $\sim 1.5$ times to that obtained using batch mode of fermentation. It was observed that initial dextrose concentration (72 $\mathrm{g} / \mathrm{L}$ ) in the fermentation medium was important for attaining high lysine productivity, while growth could be optimally sustained at dextrose concentration of $27 \mathrm{~g} / \mathrm{L}$ (Gayen and Venkatesh, 2007). The production of amino acid employing hydrolysates from rice straw and wheat bran was studied using recombinant pentose-utilizing Corynebacterium glutamicum with ethambutol as the medium supplement for enhanced production of amino acids, where 13.68 and $6.14 \mathrm{~g} / \mathrm{L}$ of glutamate and L-lysine were synthesized respectively, thus establishing the possibility of utilizing acid hydrolysate from agro-residues as the alternative and cheap substrate for large-scale amino acid production (Gopinath et al., 2011). A comparison between free and immobilized cells of $C$. glutamicum MH 20-22 B for L-lysine production showed that immobilized C. glutamicum MH 20-22 B produced $31.58(\mathrm{~g} / \mathrm{L})$ lysine, which was $20 \%$ higher as compared to free cells (Razak and Vishwanathan, 2015).

\section{Exo-Polysaccharides}

Exo-polysaccharides (xanthan, gelatine and pullulan) worth 2.25 billion dollars is sold annually. Pullulan alone had an annual demand of 10,000 tonnes (USD 250 million) in 2009 and is growing at $6.75 \%$ per year. An indigenous technology for pullulan production was developed at IMTECH (CSIR) Chandigarh using osmotolerant yeast Aureobasidium pullulans strain. The culture under optimized process conditions produced more than $70(\mathrm{~g} / \mathrm{L})$ pullulan on corn steep liquor based medium (Sharma et al., 2013). The research group showed de-oiled Jatropha oil seed 
cake as suitable nitrogen source that can be considered as cheap alternative to costly yeast extract and peptone for attaining $83.98(\mathrm{~g} / \mathrm{L})$ pullulan in $5 \mathrm{~L}$ laboratory fermenter (Roy Choudhary et al., 2012). Besides pullulan, there are also reports of novel bacterial strain Gluconacetobacter sp. F6 capable of producing $4.5(\mathrm{~g} / \mathrm{L})$ of cellulose under optimized culture conditions (Jahan et al., 2012). Similarly a novel halo-tolerant marine bacterial isolate was shown to synthesise high levels of poly(3-hydroxy butyrateo-3 hydroxyvalerate) (PHBV) (Moorkoth and Nampoothiri, 2016).

\section{Antibiotics, Biomolecules and Therapeutic Proteins}

The antibiotic market in India was worth USD 39.8 million in 2015. However, according to a report published in 2015 by Ministry of chemicals and fertilizers, Government of India, only rifamycin is being currently produced through fermentation route by two companies (Lupin and Sandoz). The fermentation of several antibiotics penicillin G, streptomycin, tertracylines, erythromycin, gentamycin and cephalosporinwas stopped during1990s, as these were not commercially viable any longer and are now imported. The search and discovery of novel biomolecules capable of combating cancer, inflammations, multi drug resistant pathogens, and life style and age related diseases (diabetes, hypercholestemia, alzheimer) are the key areas of research.

Rifamycin, a broad-spectrum antimicrobial drug effective against tuberculosis, AIDS-related mycobacterial infections and leprosy,is produced by submerged fermentation where the yields are quite low. Therefore, Nagavalli and co-workers (2015) subjected the producer strain Amycolatopsis mediterranei to sequential mutation, selection and optimization of culture conditions for developing an improved strain that produced $5.32(\mathrm{~g} / \mathrm{L})$ of rifamycin SV. In an another recent study, the efficacy of the Rifamycin B was reportedly increased using molecular biology approach for the synthesis of better analogs of rifamycin, where, Nigam et al. (2015) carried out substitution of acyltransferase domain of rifamycin polyketide synthase module 6 with rapamycin polyketide synthase module 2 . The resultant A. mediterranei $\mathrm{S} 699$ recombinant (rifAT6::rapAT2) synthesized novel rifamycin analogs, 24desmethylrifamycin B and 24-desmethylrifamycin SV, with modified polyketide backbone and exhibited enhanced antibacterial activity against several rifampicin-resistant $M$. tuberculosis strains. $A$. mediterranei $\mathrm{S} 699$ is known to carry out very tightly regulated hierarchical amino acid utilization in defined medium that influences rifamycin B fermentation dynamics (Bapat et al., 2006). The studies also showed that high production of novel glycopeptide antibiotic bahlimycin by Amycolatopsis balhimycina DSM 5908 was influenced by medium components as well as pellet morphology (Singh et al., 2012). Reports on production and structural analysis of a lipopeptide from Streptomyces amritsarensis active against methicillin-resistant Staphylococcus aureus has also been documented (Sharma et al., 2014). Isolation of novel actinomycete, Streptomyces sannanensis strain SU118 isolated from Phoomdi in Loktak Lake of Manipur that exhibited antimicrobial activity against Gram-positive bacteria only was also reported (Singh et al., 2014). Studies on isolation and production of efficient Bacillus strains for production of penicillin acylase used in the synthesis of semisynthetic penicillins have also been reported (Vellore et al., 2012; Rajendran et al., 2013).

In search of novel biomolecules from diverse microbial strains of India, Department of Biotechnology, Ministry of Science and Technology sponsored a mega project "Screening for Biomolecules from microbial diversity collected from different ecological niches" from 2007-2011.This involved nine different research institutes/universities (NEERI, Nagpur; NCCS, Pune, IGIB, New Delhi, ILS, Bhubhaneshwar, IBSD, Manipur, NIO Goa, GNDU, Amritsar, DU, Delhi and MSSRF, Chennai) for isolating diverse microorganisms from different ecological niches ranging from Himalayas, rivers, wetlands, effluents and marine samples. In three years period of project, 2, 47,000 microbial strains were isolated. The culture extracts from these were grown in three different media and methanolic extracts were subjected to robotic high throughput screening by the industrial partner in the project Piramal Life Sciences, Mumbai, for identifying microbes harbouring anticancer, anti-inflammatory, anti-diabetic and antimicrobial biomolecules. At the end of phase I of the project, 3643, 6676, 528 and 5443 three star hit cultures were identified as sources of anti-diabetic, anti- 
inflammatory, anti cancer and anti-infective biomolecules, respectively. The selected promising and novel cultures were chosen for second phase of the project for structural elucidation, production and scale up studies. One of the cultures Bacillus sp., capable of producing thiopeptide which is effective in the treatment of Clostridium difficile associated infection was patented (Mahajan et al., 2014). Piramal Life Sciences, however, discontinued its natural products division in 2015. The isolated cultures are now part of IDA approved culture repository at MCC, NCCS Pune. Presently, RPG Life Sciences, Mumbai is one of forerunner industry in India that produces life saving novel and unique products like daunorubicin, doxorubicin and epirubicin (anti-cancer drugs) in addition to cyclosporin a critical product used in organ transplant, is being produced by fermentation under stringent USP guidelines.

Statins, which are known to inhibit 3-hydroxy-3methyl glutaryl coenzyme A (HMG-CoA), are produced commercially by BIOCON India Ltd., LUPIN and Krebs Biochem. Biocon India Ltd., is the world's largest producer of lovastatin based on a proprietary solid state fermentation technology (Plafractor). This novel bioreactor configuration has the advantage of both solid substrate and submerged fermentation, and poses fewer downstream processing problems during product extraction (Sreenivasan et al., 2008). Some significant research papers in last few years have focussed on developing hyperproducing strains of Aspergillus terreus (Kaur et al., 2009) and production by pellets and immobilized $A$. terreus mycelium cells in airlift reactor by continuous culture mode (Gupta et al., 2009). Workers have also studied production of lovastatin by Monascus purpureus MTCC 369 in submerged and solid state fermentations (Sayyad et al., 2007; Panda et al., 2009). Studies reporting production of enzyme inhibitors i.e., $\alpha$-glucosidase and $\alpha$-amylase has been reported from endophytic fungi, actinobacteria like Streptomyces, Rhodococcus, Arthrobacter (Akshatha et al., 2012). These inhibitors find application in the management of diabetes, obesity andrelated disorders. The production of acetylcholinesterase (AChE) inhibitors used in treatment of neurodegenerative diseases (Alzheimer's disease, anti-cholinesterase poisoning, senile dementia, ataxia, Parkinson's diseases and myasthenia gravis) have also been reported from endophytic Alternaria sp. (Singh et al., 2012; Bhagat et al., 2016).

\section{Enzymes}

The global industrial enzyme market is expanding at a rapid rate. It was estimated at $\$ 3.8$ billion in 2011 and is expected to rise to $\$ 5.9$ billion by 2018 (Surrough et al., 2012). Enzyme production market in India is rising steadily and the current estimated annual revenues are approximately Rs 2420 million (Binod et al., 2013). Major industrial producers in India are Novozymes, Advanced Enzymes, Rossari Biotech, Zytex and Maps India, that cater to the textile, paper, leather, detergents, food, feed and pharmaceutical sectors (Singh et al., 2016). These industries use an array of enzymes like amylases, cellulases, proteases, xylanases, phytases, asparaginases, uricases and several others. Binod and co-workers (2013) have exhaustively reviewed the research and development status of different enzymes in India.

\section{Amylases}

$\alpha$-Amylase is critical and important enzyme for liquefaction of starch at high temperatures for its subsequent hydrolysis into dextrose and maltose by glucoamylases. Bacillus strains have been choicest source of $\alpha$-amylases owing to their thermostability. The researchers have continued their quest for finding novel Bacillus strains and designing cheap culture media based on cassava waste and groundnut shells for amylase production (Paul et al., 2016; Selvam et al., 216). The recombinant E. coli and Pichia pastoris clones harbouring $\alpha$-amylase gene from Bacillus acidicola TSAS1 were constructed for producing the enzyme in mixed fed batch high cell density cultivation (Prashar and Satyanarayana, 2016).

\section{Cellulases/Hemicellulases}

Cellulases, which comprise a complex of endoglucanases, cellobiohydrolases and $\beta$ glucosidases, act synergistically for deconstruction of polymeric cellulose in lignocellulosics (LC) complex into fermentable sugars (Singhania et al., 2010), therefore is an important area of R\&D for evolving novel and catalytically efficient enzymes for bioconversions of LC into ethanol and other chemicals. In addition, cellulases enzyme components individually have specific role in different detergent, textile, food 
industries (Badhan et al., 2007). The recent researches have focussed on unravelling the entire lignocellulolytic secretome of Talaromyces verruculosus SGMNPf3 (Goyari et al., 2015), Termitomyces clypeatus (Mukherjee and Khowala, 2015), Malbrancheacinna momea (Mahajan et al., 2015), Mycothermus thermophilus (Basotra et al., 2016), Penicillium funiculosum (Ogunmolu et al., 2015), Penicillium sp. Dal5 (Rai et al., 2016). Rapid purification and evaluation of catalytically distinct lignocellulolytic glycosyl hydrolases from thermo tolerant fungus Acrophialophora sp. (Rai et al., 2016) and Pyrenophora phaeocomes S-1 have also been attempted for producing cellulose and hemicelluloses hydrolyzing enzyme cocktails (Rastogi et al., 2016).

\section{Proteases}

Alkaline proteases are the most widely used enzymes which find application in detergent and leather industries. The researchers have studied the effect of amino acids on the repression of alkaline protease synthesis in halo-alkaliphilic Nocardiopsis dassonvillei (Sharma and Singh, 2016).A production technology including downstream processing andelucidation of structure-function relationship of solvent, detergent, thermo-alkali stable metalloprotease from psychrotrophic bacteria Pseudomonas putida SKG-1 was reported by Singh et al. (2013). Similarly, ametallo-protease stable at elevated temperatures from novel Bacillus alkalitelluris TWI3 isolated from tannery waste (Ananadhrajan et $a l ., 2016)$ and halo-alkaline protease from ascidianassociated Virgibacillus halodenitrificans RSK CAS1 capable of utilizing marine wastes (Sathishkumar et al., 2015) have also been reported.

\section{Phytases}

Thermophilic moulds have attracted the attention of researchers as novel sources of phytases. Recently, Humicola nigrescens as novel and efficient source of thermostable phytase for improving nutritional quality of food was reported (Jain and Singh, 2017). Another thermophilic fungus Sporotrichum thermophile has been investigated for selecting a suitable fermentation method for improved phytase production (Kumari et al., 2016). The phytase gene from $S$. thermophile has also been cloned and expressed in P. pastoris (Ranjan and Satyanarayna,
2016) and the structural and biochemical characteristics of recombinant phytase was reported by the same lab (Maurya et al., 2017). The working group has also reported optimization of heterologous expression of the Pichia anomala phytase in $P$. pastoris and its applicability in fractionating allergenic glycinin from soy protein (Joshi and Satyanarayana, 2015).

\section{Pectinases}

Pectinases find application in fruit and fibre processing industries. The researchers have focused on producing high titers of alkaline, extracellular and thermo-tolerant pectinase by a newly isolated yeast Pseudozyma sp. SPJ (Sharma et al., 2014) and attained enhanced production of pectinase by Saccharomyces cerevisiae isolate using fruit and agro-industrial wastes employing response surface methodology (Poondala et al., 2016). The pectinase from Aspergillus ibericus was produced and immobilized onto functionalized nano-porous activated carbon for the treatment of pectin containing wastewater (Mahesh et al., 2016).

\section{Pharmaceutically Important Enzymes/Proteins}

L-Asparaginase is an important enzyme that has been established for its utility in the treatment of cancer. The enzyme prevents the proliferation of cancerous cells by decreasing the level of asparagine in the blood. E. coli is preferred for L-asparaginase production because of its higher specificity for asparagine with lower glutaminase activity. Production and characterization of asparaginase has been reported from a variety of microorganisms in recent past. Production, optimization, functional and molecular characterization of novel glutaminase free Lasparaginase from Nocardiopsis alba NIOTVKMA08 was studied (Meena et al., 2015). Asparaginase from $B$. licheniformis and Pseudomonas otitidis was shown to induce apoptosis in cancerous cell lines (Mahajan et al., 2014; Husain et al., 2016). Similarly, Pseudomonas rhizohabitans was shown to be a novel source of asparaginase that reduces acrylamide in processed potato chips besides exhibiting anti-cancer activity (Bhagat et al., 2016). Asparaginase coding gene ans $B$ from $E$. coli was cloned and expressed in new phenotypic protein expression system PichiaPink ${ }^{\mathrm{TM}}$ derived from the yeast Pichia pastoris (Sajitha et al., 2015). Similarly, 
uricase is being used as therapeutic enzyme for regulating the concentration of accumulated uric acid in gout disease. The researchers have reported new microbial strains of Pseudomonas aeruginosa, Sphingobacterium thalpophilum (VITPCB5) that are capable of producing high titres of catalytically efficient uricase (Khadke et al., 2016; Ravichandran et al., 2016).

\section{Biomolecules Produced Using Recombinant- DNA}

Hindustan Antibiotics Limited (HAL) Pune, established in 1950s as a public sector drug company through Government support later diversified into production of recombinant DNA products like rHUerythropoietin (Hemax) in 1993. HAL is credited for introducing antiviral drugs for treatment of AIDS (Halpen, Haltax, Hexpan and Sati-HIV) in 2009. A technology for producing clot specific recombinantDNA based streptokinase from E. coli was developed and transferred to Shasun Drugs and Chemicals, Chennai by the Institute of Microbial Technology, Chandigarh (Sahni et al., 2007). This Clot Specific streptokinase was later developed and commercialized both in the developing countries and other worldwide markets by Nostrum Pharmaceuticals Inc., USA. In recent years, methylotrophic yeast $P$. pastoris has been used for heterologous cloning and production of different therapeutically important recombinant proteins including active streptokinase (Advitiya et al., 2016), envelope protein $\mathrm{E} 2$ gene from different genotypes of hepatitis $C$ virus (Perumal et al., 2016) and human interferon gamma (hIFN-a) (Prabhu et al., 2016). In addition, P. pastoris has also been reported for heterologous expression of lipase, nitrilase and â glucosidase (Vadhana et al., 2013; Sohoni et al., 2015; Ramani et al., 2015).

\section{Ethanol}

The annual production of ethanol in India is 2.58 billion litres, which is primarily produced from $12.48 \mathrm{MT}$ of cane molasses. The surplus ethanol (68 million litres) after its consumption in domestic (potable) and industrial sector (used as such as feedstock chemical) is now being used for blending petrol and is sold as E5 and E10 admixture in some states. The government plans to go for E20 by 2022 for which the existing molasses based ethanol will not be able to sustain the demand. Moreover, fluctuating molasses prices do not instil confidence in setting up new distilleries based on molasses. Therefore, sweet sorghum is being evaluated as source of ethanol for direct fermentation of sweet sorghum juice. The price of ethanol based on sweet sorghum has been estimated at Rs 13.60/L which is cost competitive. The existing molasses based distilleries suffer from low ethanol concentration in vats due to lower ethanol and temperature tolerance of distiller's yeast. The low ethanol content in the fermented mash means higher steam energy input for distillation of ethanol to rectified sprit (95\% (v/v). Researchers at IMTECH Chandigarh and VittalMallya Scientific Research Foundation, Bangalore jointly developed energy efficient alcohol production technology which was licensed to an Indian distillery company (UB group). The developed yeast strains produce $10 \%(\mathrm{w} / \mathrm{v})$ alcohol in the fermented mash in addition to being osmotolerantcapable of fermenting molasses at high sugar levels (25-30\%) in $30 \mathrm{~h}$. Due to higher ethanol in fermented wash, $15-20 \%$ lesser steam for distillation was required. The current focus is now directed to develop $2 \mathrm{G}$ bio-ethanol conversion technologies for utilizing abundant lignocellulosics in the form of agroresidues. The government of India (Ministry of Petroleum) announced on World Biofuel day that it plans to invest Rs 5000 crores for setting up nine $2 \mathrm{G}$ ethanol plants based on lignocellulosics to meet the demand of E20 blended petrol by 2022. The first of the demonstration $2 \mathrm{G}$ ethanol plant based on bagasse has been set up at Kashipur (Uttarakhand, India) by Glycol India. The plant is based on continuous membrane based patented technology (Lali et al., 2011) developed at DBT Bioenergy centre (ICT Mumbai). Similar 2G ethanol plants are also operational at PRAJ Industries, Pune and NIIST, Trivandrum. The technology required for lignocellulosics based ethanol platform involves various steps each with its own technical knowhow and thus leaves a wide scope for R\&D to make it commercially viable. The first step of the process involves pre-treatment of lignocellulosics so as to disintegrate lignin from the complex separating cellulose component as fibres along with hetero-polymer xylose rich hemicellulosic fraction to certain extent. The pre-treated substrate with reduced lignin content is then hydrolysed enzymatically to monomeric sugars by cellulases, hemicellulases and other auxiliary enzymes (Singhania et al., 2010; Mahajan et al., 2016). The sugar-rich 
hydrolysate that comes from saccharification primarily contains glucose and pentose sugars such as xylose/ arabinose/mannose/galactose (depending upon the composition of the LC substrate and pre-treatment process used). The fermentation of this mixed sugar hydrolysate that contains some inhibitors produced during pre-treatment of LC also poses challenge as the conventionally used yeast $S$. cerevisiae can only ferment hexoses but cannot utilize pentoses in addition to being sensitive to inhibitors. Dubey et al. (2016) evaluated the growth and fermentation efficiency of six natural yeast strains on a wide range of carbon sources, including rice and wheat straw hydrolysates, and further studied the factors that reduce the efficiency of the yeast in fermenting hydrolysates. The isolate $S$. cerevisiae MTCC4780 was found to be versatile and resulted in ethanol yields $\left(\mathrm{Y}_{\mathrm{p} / \mathrm{s}}\right)$ of $0.48 \mathrm{~g} / \mathrm{g}, 0.42 \mathrm{~g} / \mathrm{g}$ and $0.45 \mathrm{~g} / \mathrm{g}$, respectivelyduring fermentation of glucose, rice and wheat straw enzymatic hydrolysates in a bioreactor. The yeast isolates MTCC4781 and MTCC4796 were comparatively better producers of ethanol at elevated temperature and were able to tolerate theinhibitors. Debaryomyce shansenii (Menon et al., 2010) and Pichia strain BY2 capable of fermenting xylose have

\section{References}

Adivitiya, Dagar VK, Devi N and Khasa YP (2016) High level production of active streptokinase in Pichia pastoris fedbatch culture Int J Biol Macromol 83 50-160

Adsul M,Khire J, Bastawde K and Gokhale D (2007) Lactic acid production from cellobiose and cellotriose by Lactobacillus delbrueckii mutant Uc-3 Appl Environ Microbiol 73 50555057

Agarwal L, Isar J, Dutt K and Saxena R (2007) Statistical optimization for succinic acid production from $E$. coli in a cost-effective medium Appl Biochem Biotechnol 142158

Akshatha VJ, Nalin MS, D’Souza C and Prakash HS (2014) Streptomycete endophytes from anti-diabetic medicinal plants of the Western Ghats inhibit alpha-amylase and promote glucose uptake Lett Appl Microbiol 58 433-439

Anandharaj M, Sivasankari B, Siddharthan N, Rani RP and Sivakumar S (2016) Production, purification, and biochemical characterization of thermostable metalloprotease from novel Bacillus alkalitelluris TWI3 isolated from tannery waste Appl Biochem Biotechnol 178 16661686 been isolated from over-ripe banana (Hande et al., 2013). The other important aspect in focus is the search for thermotolerant yeast that can be used for simultaneous saccharification and fermentation (SSF) of sugars in hydrolysates. The conventional yeast $S$. cerevisiaeferments actively at temperature between $28-33^{\circ} \mathrm{C}$, therefore, can only be inoculated after enzymatic hydrolysis step which is carried out at $50^{\circ} \mathrm{C}$, after adjusting the temperature. Therefore researchers have attempted simultaneous saccharification and fermentation (SSF) for bioconversion of alkali treated rice straw usingthermotolerant yeast Pichia kudriavzevii HOP1, Blastobotrysaden inivorans RCKP 2012 strains (Oberoi et al., 2012; Antil et al., 2015). Kumar and co-workers (2015) identified very efficient thermotolerant yeast Kluyveromyces sp. IIPE453 capable of fermenting both xylose and glucoserich bagasse hydrolysate obtained from the two-stage acid hydrolysis to $183 \mathrm{~g}$ xylitol and $165 \mathrm{~g}$ ethanol per $\mathrm{kg}$ bagasse. An oleaginous yeast strain Cryptococcus vishniaccii has also been reported recently for bioconversion of paper mill sludge into neutral lipids for biodiesel production (Deeba et al., 2016).

Antil PS, Gupta R and Kuhad RC (2015) Simultaneous saccharification and fermentation of pretreated sugarcane bagasse to ethanol using a new thermotolerant yeast Ann Microbiol 65423

Badhan A, Chadha BS, Kaur J, Saini HS and Bhat MK (2007) Production of multiple xylanolytic and cellulolytic enzymes by thermophilic fungus Myceliophthora sp. IMI 387099 Bioresour Technol 98 504-510

Bapat PM, Das D, Sohoni SV and Wagnikar PK (2006) Hierarchical amino acid utilization and its influence on fermentation dynamics: rifamycin B fermentation using Amycolatopsisme diterranei S699, a case study Microb Cell Fact 532

Basotra N, Kaur B, Di Falco M, Tsang A and Chadha BS (2016) Mycothermus thermophilus (Syn. Scytalidium thermophilum): Repertoire of a diverse array of efficient cellulases and hemicellulases in the secretome revealed Bioresour Technol 222 413-421

Bhagat J, Kaur A and Chadha BS (2016) Single step purification of asparaginase from endophytic bacteria Pseudomonas oryzihabitans exhibiting high potential to reduce acrylamide in processed potato chips Food Bioprod Process 99 222- 
230

Bhagat J, Kaur A, Kaur R, Yadav AK, Sharma V and Chadha BS (2016) Cholinesterase inhibitor (Altenuene) from an endophytic fungus Alternariaalternata: optimization, purification and characterization $J$ Appl Microbiol 121 1015-25

Binod P, Palkhiwala P, Gaikaiwari R, Nampoothiri KM, Duggal A, Dey K and Pandey A (2013) Industrial enzymes: present status and future perspectives for India: present scenario and perspectives $J$ Sci Ind Res 72 271-286

Deeba F, Pruthi V and Negi YS (2016) Converting paper mill sludge into neutral lipids by oleaginous yeast Cryptococcus vishniaccii for biodiesel production Bioresour Technol 213 96-102

Dey P, Sikder J, Roy S and Paul P (2012)Fermentative lactic acid production from a renewable carbon source under response surface optimized conditions without alkali addition: a membrane-based green approach Clean Techn Environ Policy 14 827-835

Dubey R, Jakeer S and Gaur NA (2016) Screening of natural yeast isolates under the effects of stresses associated with second-generation biofuel production J Biosci Bioengg 121 509-516

Dumbrepatil A, Adsul M, Chaudhari S, Khire J and Gokhale D (2008) Utilization of molasses sugar for lactic acid production by Lactobacillus delbrueckii sub sp. delbrueckii mutant Uc-3 in batch fermentation Appl Environ Microbiol 74 333-335

Gayen K and Venkatesh KV (2007) A phenomenological model to represent the kinetics of growth by Corynebacterium glutamicum for lysine production $J$ Ind Microbiol Biotechnol 34 363-372

Gopinath V, Meiswinkel TM, Wendisch VF and Nampoothiri KM (2011)Amino acid production from rice straw and wheat bran hydrolysates by recombinant pentose-utilizing Corynebacterium glutamicum Appl Microbiol Biotechnol 92 985-96

Goyari S, Devi SH, Bengyella L, Khan M,Sharma CK, Kalita MC and Talukdar NC (2015) Unveiling the optimal parameters for cellulolytic characteristics of Talaromyce sverruculosus SGMNPf3 and its secretory enzymes J Appl Microbiol 119 88-98

Gupta K, Mishra PK and Srivastava P (2009) Enhanced continuous production of lovastatin using pellets and siran supported growth of Aspergillus terreus in an airlift reactor Biotechnol Bioprocess Eng 14 207-212

Hande A, Mahajan S and Prabhune A(2013) Evaluation of ethanol production by a new isolate of yeast during fermentation in synthetic medium and sugarcane bagasse hemicellulosic hydrolysate Ann Microbiol 63 63-70

Husain I, Sharma A, Kumar S and Malik F (2015) Purification and characterization of glutaminase free asparaginase from Pseudomonas otitidis: Induce apoptosis in human leukemia MOLT-4 cells Biochimie 121 38-51

Jahan F, Kumar V, Rawat G and Saxena RK (2012) Production of microbial cellulose by a bacterium isolated from fruit $\mathbf{1 6 7}$ 1157-1171

Jain J and Singh B (2017) Phytase production and development of an ideal dephytinization process for amelioration of food nutrition using microbial phytases Appl Biochem Biotechnol 181 1485-1495

Joshi S and Satyanarayana T (2014) Optimization of heterologous expression of the phytase (PPHY) of Pichia anomala in $P$. pastoris and its applicability in fractionating allergenic glycinin from soy protein J Ind Microbiol Biotechnol 41 977-987

Kaur H, Kaur A, Saini HS and Chadha BS (2009) Screening and selection of lovastatin hyper-producing mutants of Aspergillus terreus using cyclic mutagenesis Acta Microbiol Immunol Hung 56 169-180

Khadke S, Srivastava SK and Tripathi AD (2016) Production of clinically efficient uricase enzyme induced from different strains of Pseudomonas aeruginosa under submerged fermentations and their kinetic properties Biocatal Agric Biotechnol 8 139-145

Kumar D, Verma R and Bhalla TC (2010) Citric acid production by Aspergillus niger van. Tieghem MTCC 281 using waste apple pomace as a substrate $J$ Food Sci Technol 47 458460

Kumar S, Dheeran P, Singh SP, Mishra IM and Adhikari DK (2015) Bioprocessing of bagasse hydrolysate for ethanol and xylitol production using thermotolerant yeast Bioprocess Biosyst Eng 38 39-47

Kumari A, Satyanarayana T and Singh B (2016) Mixed substrate fermentation for enhanced phytase production by thermophilic mould Sporotrichum thermophile and its application in beneficiation of poultry feed Appl Biochem Biotechnol 178 197-210

Lali A M (2011) A process for fractionation of biomass US patent No WO 2011/154962 A1

Mahajan C, BasotraN, Singh S, Di Falco M, Tsang A and Chadha BS (2016) Malbranchea cinnamomea: A thermophilic fungal source of catalytically efficient cellulase/ hemicellulases and metal dependent enzymes Bioresour Technol 200 55-63

Mahajan G, Kate A, Ranadive P, Chadha BS, Shouche Y, Purohit 
HJ and Balakrishnan A (2013) Use of a thiopeptide compound in the treatment of Clostridium difficile associated infections US patent No: 61/898,237

Mahajan RV, Kumar V, Rajendran V, Saran S, Ghosh PC and Saxena RK (2014) Purification and characterization of a novel and robust 1-asparaginase having low-glutaminase activity from Bacillus licheniformis: in vitro evaluation of anticancerous properties PLoS One 9 e99037

Mahesh M, Arivizhivendhan KV, Maharaja P, Boopathy R, Hamsavathani V and Sekaran G (2016) Production, purification and immobilization of pectinase from Aspergillus ibericus onto functionalized nanoporous activated carbon (FNAC) and its application on treatment of pectin containing wastewater J MolCatal B: Enzym 133 43-54

Meena B, Anburajan L, Dheenan PS, Begum M, Vinithkumar NM, Dharani G and Kirubagaran R (2015) Novel glutaminase free L-asparaginase from Nocardiopsis alba NIOT-VKMA08: production, optimization, functional and molecular characterization Bioprocess Biosyst Eng 38 373-388

Menon V, Prakash G, Prabhune A and Rao M (2010) Biocatalytic approach for the utilization of hemicellulose for ethanol production from agricultural residue using thermostable xylanase and thermotolerant yeast Bioresour Technol 101 5366-73

Moorkoth D and Nampoothiri KM (2016) Production and characterization of poly (3-hydroxy butyrate-co-3 hydroxyvalerate) (PHBV) by a novel halotolerant mangrove isolate Bioresour Technol 201 253-260

Maurya AK, Parashar D and Satyanarayana T (2017) Bioprocess for the production of recombinant HAP phytase of the thermophilic mold Sporotrichum thermophile and its structural and biochemical characteristics Int $J$ Biol Macromol 94 36-44

Mukherjee S and Khowala S (2016) Unraveling the secretome of Termitomycesclypeatus grown on agroresidues as a potential source for bioethanol production Proc Biochem 51 1793-1807

Nagavalli M, Ponamgi SPD, Girijashankar V and Rao LV (2015) Enhanced rifamycin SV production by submerged fermentation using Amycolatopsismediterranei Appl Microbiol Biotechnol 997505

Nigam A, Almabruk KH, Saxena A, Yang J, Mukherjee U, Kaur H, Kohli P, Kumari R, Singh P, Zakharov LN, Singh Y, Mahmud Tand Lal R (2014) Modification of rifamycin polyketide backbone leads to improved drug activity against rifampicin-resistant Mycobacterium tuberculosis J Biol
Chem $28921142-52$

Oberoi HS, Babba N, Sandhu SK, Dhaliwal SS, Kaur U, Chadha BS and Bhargav VK (2012) Ethanol production from alkalitreated rice straw via simultaneous saccharification and fermentation using newly isolated thermotolerant Pichia kudriavzevii HOP-1 J Ind Microbiol Biotechnol $39557-$ 566

Ogunmolu FE, Kaur I, Gupta M, Bashir Z, Pasari N and Yazdani SS (2015) Proteomics insights into the biomass hydrolysis potentials of a hypercellulolytic fungus Penicillium funiculosum J Proteome Res 14 4342-58

Panda BP, Javed S and Ali M (2009) Statistical analysis and validation of process parameters influencing lovastatin production by Monascus purpureus MTCC 369 under solid-state fermentation Biotechnol Bioproc Eng 14 123127

Parashar D and Satayanayana T (2016) Enhancing the production of recombinant acidic $\alpha$-amylase and phytase in Pichia pastoris under dual promoters [constitutive $(G A P)$ and inducible $(A O X)]$ in mixed fed batch high cell density cultivation Proc Biochem 51 1315-1322

Paul JS, Lall BM, Jadhav SK and Tiwari KL (2016) Parameter optimization and kinetics study of $\alpha$-amylase enzyme of Bacillus sp. MB6 isolated from vegetable waste Proc Biochem 181 1485-1495

Perumal SP, Wilson S and Santhiagu A (2016) Optimization of codon usage of the envelope protein $\mathrm{E} 2$ gene from various genotypes of hepatitis $\mathrm{C}$ virus to predict the expression level in Pichia pastoris Genes Genomics 38 977-984

Poondla V, Yannam SK, Gummadi SN, Subramanyam R and Obulam VSR (2016) Enhanced production of pectinase by Saccharomyces cerevisiae isolate using fruit and agroindustrial wastes: Its application in fruit and fiber processing Biocatal Agric Biotechnol 6 40-50

Prabhu AA, Veeranki VD and Dsilva SD (2016) Improving the production of human interferon gamma (hIFN- $\gamma$ ) in Pichia pastoris cell factory: An approach of cell level Proc Biochem 51 709-718

Puri M, Chugh SK and Singh RS (2007) A novel strain of Aspergillus for the production of gluconic acid and the process therefore Indian Patent No. 1449/DEL/2007

Rai R, Kaur B and Chadha BS (2016) A method for rapid purification and evaluation of catalytically distinct lignocellulolytic glycosyl hydrolases from thermotolerant fungus Acrophialophora sp. Renew energy 98 254-263

Rai R, Kaur B, Singh S, Di Falco M, Tsang A and Chadha BS (2016) Evaluation of secretome of highly efficient lignocellulolytic Penicillium sp. Dal 5 isolated from 
rhizosphere of conifers Bioresour Technol 216 958-967

Rajendran K, Mahadevan S, Jeyaprakash R, Gurunasekran P and Mandal A (2013) Strategies for enhancing the production of penicillin g acylase from Bacillus badius: Influence of phenyl acetic acid dosage Appl Biochem Biotechnol 171 1328-1338

Raksha S, Srinivasan S, Prasant G and Prabu R (2012)Overexpression of gluconic acid in Aspergillus oryzae RP-21 mutants generated by a random mutagenesis approach 3 Biotech 2 219-223

Ramani G, Meera B, Vanitha C, Rajendhran J and Gunasekaran P (2015) Molecular cloning and expression of thermostable glucose-tolerant $\beta$-glucosidase of Penicillium funiculosum NCL1 in Pichia pastoris and its characterization $J$ Ind Microbiol Biotechnol 42 553-565

Ramesh T and Kalaiselvam M (2011) Anexperimental study on citric acid production by aspergillus niger using Gelidiella acerosa as a substrate Indian J Microbiol 51 289-293

Ranjan Band Satyanarayana T (2016) Recombinant HAP phytase of the thermophilic mold Sporotrichum thermophile: Expression of the codon-optimized phytase gene in Pichia pastorisand applications Mol Biotechnol 58 137-47

S Rastogi, Soni R, Kaur J and Soni SK (2016) Unravelling the capability of Pyrenophoraphaeocomes S-1 for the production of ligno-hemicellulolytic enzyme cocktail and simultaneous bio-delignification of rice straw for enhanced enzymatic saccharification Bioresour Technol 222 458469

Ravichandran R, Hemaasri S, Cameotra SS and Jayaprakash NS (2015) Purification and characterization of an extracellular uricase from a new isolate of Sphingobacterium thalpophilum (VITPCB5) Protein Expr Purif 114 136-142

Razak MA and Viswanath B (2015) Optimization of fermentation upstream parameters and immobilization of Corynebacterium glutamicum $\mathrm{MH} 20-22$ B cells to enhance the production of L-lysine 3 Biotech 5531

Choudhury AR, Sharma N and Prasad GS (2012) Deoiledjatropha seed cake is a useful nutrient for pullulan production Microb Cell Fact 1139

Sahni G, Kumar R, Roy C, Rajagopal K, Nihalani D, Sundaram V and Yadav M (2007) Clot specific streptokinase proteins processing altered plasminogen activation characteristics and a process for their preparation US Patent no. 7163817

Sajitha S, Vidya J, Varsha K, Binod P and Pandey A (2015) Cloning and expression of L-asparaginase from $E$. coli in eukaryotic expression system Biochem Engg J 102 14-17

Sathishkumar R, Ananthan G and Raghunathan C (2015) Production and characterization of haloalkaline protease from ascidian-associated Virgibacillus halodenitrificans RSK CAS1 using marine wastes Ann Microbiol 65 14811493

Sayyad SA, Panda BP, Javed S and Ali M (2007) Optimization of nutrient parameters for lovastatin production by Monascus purpureus MTCC 369 under submerged fermentation using response surface methodology Appl Microbiol Biotechnol 73 1054-1058

Seenivasan A, Subhagar S, Aravindan R and Viruthagiri T (2008) microbial production and biomedical applications of lovastatin J Pharm Sci 70 701-709

Selvam K, Selvankumar T, Rajiniganth R, Srinivasan P, Sudhakar C, Senthilkumar B and Muthusamy G (2016) Enhanced production of amylase from Bacillus sp. using groundnut shell and cassava waste as a substrate under process optimization: Waste to wealth approach Biocatal Agri Biotechnol 7 250-256

Sharma AK and Singh SP (2016) Effect of amino acids on the repression of alkaline protease synthesis in haloalkaliphilic Nocardiopsisdassonvillei Biotechnol Report 12 40-51

Sharma D, Mandal SM and Manhas RK (2014) Purification and characterization of a novel lipopeptide from Streptomyces amritsarensis sp. nov. active against methicillin-resistant Staphylococcus aureus AMB Express 450

Sharma N, Prasad GS and Roy Choudhury A(2013) Utilization of corn steep liquor for biosynthesis of pullulan, an important exopolysaccharide Carbohydr Polym 93 95101

Sharma S, Sharma J and Mandhan RP (2014) Lucrative pectinase production by novel strain Pseudozyma sp. SPJ with statistical optimization techniques using agro-industrial residues Front Biol 9 317-323

Singh B, Thakur A, Kaur S, Chadha B and Kaur A (2012) Acetylcholinesterase inhibitory potential and insecticidal activity of an endophytic Alternaria sp. from Ricinuscommunis Appl Biochem Biotechnol 168 991-1002

Singh KP, Wangikar PP and Jadhav S (2012) Correlation between pellet morphology and glycopeptide antibiotic balhimycin production by Amycolatopsis balhimycina DSM $5908 \mathrm{~J}$ Ind Microbiol Biotechnol 3927

Singh LS, Sharma H and Talukdar NC (2014) Production of potent antimicrobial agent by actinomycete, Streptomyces sannanensis strain SU118 isolated from phoomdi in Loktak Lake of Manipur, India BMC Microbiol 14278

Singh R, Kumar M, Mittal A and Mehta PK (2016) Microbial enzymes: Industrial progress in 21 st century 3 Biotech 6 174 
Singh SK, Tripathi VR, Garg SK and Khare SK (2013) Downstream processing, characterization, and structurefunction relationship of solvent-, detergent-, psychro-, thermo-, alkalistable metalloprotease from metal-, solventtolerant psychrotrophic Pseudomonas putida SKG-1 Isolate Biotechnol Prog 29 99-108

Singhania RR, Sukumaran RK, Patel AK, Larroche C and Pandey A (2010) Advancement and comparative profiles in the production technologies using solid-state and submerged fermentation for microbial cellulases Enzyme Microb Technol 46 541-549

Sohoni SV, Nelapati D, Sathe S, Subhedar VJ, Gaikaiwari RP and Wangikar PP (2015) Optimization of high cell density fermentation process for recombinant nitrilase production in E. coli Bioresour Technol 188 202-208
Solomon S (2011) Sugarcane by-products based industries in India Sugar Tech 13 408-416

Vadhana ASP, Samuel PS, Berin RM, Krishna J, Kamatchi K and Meenakshisundaram S (2013) Improved secretion of Candida antarctica lipase B with its native signal peptide in Pichia pastoris Enzyme Microb Technol 52 177183

Vandenberghe LPS, Soccol CR, Prado FC and Pandey A (2004) Comparison of citric acid production by solid-state fermentation in flask, column, tray, and drum bioreactors Appl Biochem Biotechnol 118 293-303

Vellore SA, Kumar A, Naik N and Pundale AV (2012) Characterization of a new Bacillus cereus ATUAVP1846 strain producing penicillin $\mathrm{V}$ acylase and optimization of fermentation parameters Ann Microbiol 62 1287-1293. 